Original Contribution

\title{
EXPLAIN THE ROLE OF DIFFERENT MEDIA AS AN EFFECTIVE INSTRUMENT OF ECONOMIC MUTATION IN SPORTS SECTOR
}

\author{
F. Zohrabi ${ }^{1}$, A. Shahsavari ${ }^{1}$, M. Rooham ${ }^{2}$, S. R. Mousavi ${ }^{3}{ }^{*}$ \\ ${ }^{1}$ Department of Physical Education, Payame Noor University, Tehran, Iran \\ ${ }^{2}$ Samen Branch, Islamic Azad University, Samen, Iran \\ ${ }^{3}$ Young Researchers and Elites Club, Science and Research Branch, Islamic Azad University, Tehran, Iran
}

\begin{abstract}
The aim of the present study was to investigate the role of different media as an effective instrument of economic mutation in sports sector based on the eight selected solutions of the athletic development in Iran. The views of 75 officials in various sports federations were collected, that were selected based on a Cohen's sample table. Measuring instrument was a researcher-made questionnaire with 56 questions constructed through The Delphi method. The questionnaire reliability and validity were confirmed by means of Cronbach's alpha test 0.87 and the simulative method respectively. Friedman's test was used to prioritize the role of each types of media in the eight developing strategies of athletic sport, also Kruskal-Wallis test was used to determine the contribution of each media on the eight strategies for sports development. The results showed that, print media had a greater role in the women's sports development, and the new visual media (internet, TV, etc.) had the greatest role in the marketing development, academic sports development, hosting international competition, and attract foreign investment. Based on the results obtained, visual media had the greatest impact on meritocracy and specialization, attracting inward investment and privatization. In addition, media can also play the most significant role in attract foreign investment, hosting international competitions and sports marketing respectively.
\end{abstract}

Key words: Media, economy, sports, marketing, development

\section{INTRODUCTION}

Developed countries have put health of human resources and thus sports activities as a priority in their policies and programs to achieving a higher status in international relations. Meanwhile athletic sport is particularly important to creating incentives, self-confidence and vitality, talent development, emotional control, socialization, identity, and enhance national pride. It should be noted that all human activities, including sports development including sports require development, wealth creation and added value for their consistency. In this regard, the sports industry has gained the $6^{\text {th }}$ rank among the superior industries of the world because of the efforts of the people involved in sports and the considerable economic growth (1).

*Correspondence to: S. R. Mousavi, Young Researchers and Elites Club, Science and Research Branch, Islamic Azad University, Tehran, Iran.(Correspondence to: Sayed Roholla Mousavi. Tel:+98-21-44865154.rr_mousavi@yahoo.com
However, the sports industry's share of GDP is estimated to be 1.1 percent (2). On one hand, the development of sports industry is bound to enough financial resources and investment to execute the strategic programs and provide sports services through using skilled human resources, standard and advanced equipment and infrastructure in different fields of sports. Nowadays most of countries, as a result of the shortage of domestic resources and the increase of their own economic systems, have a strong desire to attract foreign investment. Studies have shown that foreign investment can be very high enhancing in terms of the production of goods and services in the investment attractor countries (3). The major principle of economy and wealth production is obtaining the maximum results, satisfaction and acceptance of people with the minimal effort or cost. But in order to achieve such an important goal in the present state of the Iran, numerous sanctions, and the contrast between the world an "evolution"-like endeavour 
ZOHRABI F., et al.

is required. Economic evolution or labor in sports can be defined as the establishment of the new way of thinking and behavior, and the more attempt to maximize the satisfaction of society members from this important social phenomenon. Such evaluation must bring about wealth production, the optimal allocation of services, and increase in the public welfare. Elahi and Mozaffari (2009) states that domestic and foreign investment, scientific development, hosting international competition, privatization, marketing, development of women's sports and meritocracy is the most important strategic solution of developing championship sports (4). It seems that any attempt to facilitate these solutions will lead to the production of wealth, prosperity and fulfillment of services and welfare, and realization of economic evolution. But the important question is, in order to successfully apply and maintain these experiments what instruments and how should be used? One of the most important factors affecting the development of the sport in the 1990s has been a media (5). Media, as the most effective form of mass communication are divided into six types:

-Print media such as newspapers and book.

-Audio media: such as radio.

- Visual media such as cinema, television and new visual internet.

-Instrumental media such as leaflets, catalogs, brochures, billboards, posters, tract, slogans, stand board, logos, label, teaser, short and long films, plays, lectures, and different types of meetings.

- Institutional media such as media group or media institution like public relations, publishing companies, cinema institutes, radio, television, press offices etc.

-Cross-institutional media such as press, news center, office of international relations, cartels, broadcasters, press trusts, multinational filmmaker companies and satellite networks (6).

Ghiami Rad (2009) reported a significant relationship between the mass media support and the development and promotion of sports fields (1). Sajjadi (2007) also mentioned the use of sports imagery in corporate and consequently gaining high income as one of the appropriate solutions to domestic companies marketing strategies (7). Since 1960's sport and economy have interacted with each other as a result of media development and the commercialization process of the sport took on a new form . The interaction has had mutual benefits of both the sport and the economy. On one hand, economy with the help of numerous addressees and fans in sports area could find a better market and promote its products. On the other hand, sports taking advantage of economical investment could also promote the capacity of infrastructure scope, develop quantitatively and qualitatively, revolutionize the athletes' financial status and create a new atmosphere called professionalization (1). Rudock (2010) reports the multi-million dollar profits from the creation of a website for fans of the Australian Football League teams (8). This important issue seems naturals because the use of the internet and the web has accelerated in human's daily life and Loakimidis (2010) Johnson notes that today, sports online marketing has become the best place for bringing together fans, professional sports teams and leagues (9). Among the various forms of sports, the media due to the economic aspects pay more attention to the athletics (championship sports) so that the major television networks of recent decades have produced and broadcast sports competitions from the most popular television programs, with major contracts with the International Olympic Committee. Based on the above mentioned materials and according to the status and place of the sports federations which are the main source of decision-making about the sports field of the athletics in the Iran, the role that different types of media were studied as the effective means of wealth production and evolution movement in sports are a play on the strategic solutions of the championship sports from the perspective of those involved in sports federations.

\section{METHODOLOGY}

This research is of a descriptive - analytical type and its objective is practical (applied). First 12 sports federations of basketball, volleyball, cycling, judo, archery, karate, wrestling, swimming, table tennis, weightlifting, track \&field, and football were selected out of all Olympic federations. The research population of the research is the all staff involved with Bachelor's degree and above (145 people). The sample size was determined based on the sample table of Cohen, Morgan, Grjsay, and after frequent follow-up attempts the researchers could collect and analyze 75 questionnaires. Due to the lack of an accurate and reliable means by which the role of media in the economic evolution of the athletics could be measured, questionnaire construction and validation was processed as one of the ancillary necessities of 
the present study. Surveying the theoretical basis of the research and the similar- to some extentquestionnaires, and using the perspectives and attitudes of the experts and specialists, the final questionnaire was prepared based on the research objectives. In this questionnaire, the extent to which each research participant (those involved in sports federations) was familiar with and used different types of media including visual, print, audio, new visual, instrumental, institutional and cross-institutional was taken into account. Among the various factors affecting economic Jihad of the championship sport, the eight factors of institutionalizing meritocracy in the federations, the development of women's sports share, academic development, privatization, sports marketing, hosting international competitions, attracting investment from domestic and foreign sources were determined. Finally the questionnaire was constructed in order to survey the role of each of the media types in the eight factors of the economic evolution of championship sports. hen, in a preliminary study and using several numbers of the specialists and experts of media and sport
ZOHRABI F., et al. through the Delphi method (giving questionnaires to the experts and receiving their perspectives and attitudes in several stages) the final questionnaire was completed with 56 questions and based a five-valued Likert -scale. The validity of the questionnaire was calculated using the simulative method and the reliability achieved using Alpha Croanbach $0.78 \%$. According to the statistics of Kolmogorov Smirnov test the data did not have natural distribution. So the Friedman test was tailored to prioritize the extent to which each of the seven types of the media play in the eight solutions of the championship sports development. In addition, Kruskal-Wallis test was used to determine the share each of the media have in the eight solutions for sports development.

\section{RESULTS}

Tables 1 to 9 shows the Friedman and KruskalWallis test results on the role of media in improving the Iran's championship sports development as one of the examples of economic evolution in the sports area.

Table 1. Results of the Friedman test; the role of media in women's sport participation

\begin{tabular}{cc}
\hline Media type & Average rating \\
\hline Print & 357 \\
Visual & 333.5 \\
Cross-Institutional & 316.5 \\
New Visual & 280.5 \\
Instrumental & 279.5 \\
Audio & 276.5 \\
Institutional & 256.5 \\
Freidman & 32.65 \\
\hline Significance Level & 0.0001 \\
\hline
\end{tabular}

According to Table $\mathbf{1}$ from the research participants' view the print media can play the most significant role in the development of women's sports. Then visual media, crossinstitutional media, new visual media, instrumental media, audio media and institutional media come next respectively.

According to Table 2 from the research participants' view the new visual media can play the most significant role in the scientific development of sports. Then, print media, visual media, audio media, instrumental media, crossinstitutional media, and institutional media are placed in the following ranks respectively.

Based on Table 3 from the research participants' view the visual media can play the most significant role in privatization. Then, new visual media, print media, cross-institutional media, institutional media, instrumental media, and audio media take the following ranks respectively. 
Table 2. Friedman test results, the role of the media in scientific development

\begin{tabular}{cc}
\hline Media type & Average rating \\
\hline New visual & 406.5 \\
Print & 340.5 \\
Visual & 329 \\
Audio & 272.5 \\
Instrumental & 270 \\
Cross-institutional & 260.5 \\
Institutional & 221 \\
Friedman & 91.78 \\
\hline Significance level & 0.0001 \\
\hline
\end{tabular}

Table 3. Friedman test results, the role of the media in privatization

\begin{tabular}{cc}
\hline Media type & Average rating \\
\hline Visual & 383.5 \\
New Visual & 333 \\
Print & 5.329 \\
Cross-Institutional & 306.5 \\
Institutional & 262.5 \\
Instrumental & 244.5 \\
Visual & 240.5 \\
Friedman & 70.13 \\
\hline Significance Level & 0.0001 \\
\hline
\end{tabular}

Table 4. Friedman test results, the role of the media in sports marketing

\begin{tabular}{cc}
\hline Media type & Average rating \\
\hline New Visual & 376 \\
Visual & 347.5 \\
Print & 328 \\
Instrumental & 301.5 \\
Cross-Institutional & 293 \\
Audio & 234 \\
Institutional & 220 \\
Friedman & 78.47 \\
\hline Significance Level & 0.0001 \\
\hline
\end{tabular}

As shown in Table 4 from the research participants' view the new visual media can play the most significant role in sports marketing. Then, visual media, print media, instrumental media, cross-institutional media, audio media, and institutional media are placed in the following ranks respectively.
Based on Table 5 from the research participants' view the new visual media can play the most significant role in hosting international competitions. Then visual media, print media, cross-institutional media, instrumental media, audio media, and institutional media come next respectively. 
Table 5. Friedman test results, the role of the media in hosting international competitions

\begin{tabular}{cc}
\hline Media type & Average rating \\
\hline New Visual & 390 \\
Visual & 345 \\
Print & 330 \\
Cross-Institutional & 320.5 \\
Instrumental & 258 \\
Audio & 235.5 \\
Institutional & 221 \\
Friedman & 101.19 \\
\hline Significance Level & \\
\hline
\end{tabular}

Table 6. Friedman test results, the role of the media in attracting domestic investments

\begin{tabular}{cc}
\hline Media type & Average rating \\
\hline Visual & 374 \\
Cross-Institutional & 322.5 \\
New Visual & 320.5 \\
Print & 306.5 \\
Instrumental & 271.5 \\
Institutional & 263.5 \\
Visual & 242 \\
Friedman & 52.04 \\
\hline Significance Level & 0.0001 \\
\hline
\end{tabular}

As shown in Table 6 from the research participants' view the visual media can play the most significant role in attracting domestic investments. Then cross-institutional media, new visual media, print media, instrumental media, institutional media, and audio media are placed in the following ranks respectively.

Table 7. Friedman test results, the role of the media in attracting foreign investments

\begin{tabular}{cc}
\hline Media type & Average rating \\
\hline New Visual & 444.5 \\
Cross-Institutional & 342.5 \\
Visual & 316.5 \\
Instrumental & 274.5 \\
Print & 263.5 \\
Institutional & 262 \\
Audio & 196.5 \\
Friedman & 149.39 \\
\hline Significance Level & 0.0001 \\
\hline
\end{tabular}

According to Table 7 from the research participants' view the new visual media can play the most significant role in attracting foreign investments. Then cross-institutional media, visual media, instrumental media, print media, institutional media, and audio media come at the next ranks respectively.
As shown in Table 8 from the research participants' view the visual media can play the most significant role in meritocracy. Then print media, new visual media, cross-institutional media, audio media, instrumental media, and institutional media, are placed in the following ranks respectively. 
Table 8. Friedman test results, the role of the media in meritocracy

\begin{tabular}{cc}
\hline Media type & Average rating \\
\hline Visual & 394 \\
Print & 357 \\
New visual & 308.5 \\
Cross-institutional & 304 \\
Audio & 275 \\
Instrumental & 254 \\
Institutional & 212 \\
Friedman & 80.47 \\
\hline Significance level & 0.0001 \\
\hline
\end{tabular}

Table 9. Kruskal-Wallis test results, the role of the media in championship sports development strategies.

\begin{tabular}{cc}
\hline Championship sports development strategies & Average rating \\
\hline Attracting foreign investment & 4583.9 \\
Hosting international competitions & 4554.1 \\
Sports marketing & 4471.1 \\
Privatization & 4334.9 \\
Attracting domestic investment & 4177.9 \\
Scientific development & 4075.6 \\
Development share of women's sports & 3865.3 \\
Institutionalizing democracy and specialization & 3436.9 \\
Kruskal-Wallis & 527.29 \\
\hline Significance level & 0.0001 \\
\hline
\end{tabular}

Table 9 shows that media can have the most important role in attracting foreign investment. Then the most important role is allocated to hosting international competitions, sports marketing, privatization, domestic investment, scientific development, the development of women's sports, meritocracy.

\section{DISCUSSION}

Recent years have been the advent of the efficient and powerful media in all social, political, economic and cultural phenomena. In this regard, the media has been called as the powerful means of human societies and the fourth principle of the governments are. The findings of the present research also suggest the effective role of media, particularly the new visual media, (Internet, Web, etc.) and visual (TV, etc.) in the development of athletics (championship sports). These findings are consistent and in line with 4, 10 and 9. Finding about the positive impact of media advertising on investment attraction, development of financial resources of the sports organizations, sports marketing development etc. Broadcasting right in most of these studies in order to attract financial resources effectively in various sectors is an interesting point to be mentioned here. This right is of the most important resources of the private sector which is in addition to the resources considered by public and governmental organizations for the development and implementation of sports program. Today position of international sports organizations is grateful to television revenues from the sector during the second half of the twentieth century onwards; because revenue growth was initiated from 1960 Olympics and culminating in the London 2012 Olympics. But in Iran televised games, will not be considered as the rights, but as a favour from broadcasting to the owner of the games (11). However, the negative roles of the media in privatization such as providing false information, spreading rumours, and wrong analysis by the experts or unaware people about the privatization concern every member of the society (7). Creating a new way of thinking and behaviour and trying more to produce wealth and obtain maximum results, satisfaction and compliance achieved with minimum effort or cost in sports is the real meaning of economic Jihad in supplying such an important social phenomenon. Therefore, finding the tools and techniques that facilitate access to it is the most basic responsibility of those involved with (people who hold a position in) the sports of the country.

The findings of the present study suggest that the new visual media such as the Internet, the Web, 
etc. Could play the most important role in the scientific development of sports, sports marketing, hosting international competitions, and attracting foreign investments which are consistent with 9 and 10 findings about the impact of the Internet on marketing and attracting investment. The internet can have a big impact on sports marketing interactions, but our share of this effect is very trivial in the country. Therefore, the society needs a particular attention and consideration in preparing infrastructure in order for implementation of this media in the sports marketing equation and obviously wealth production in sports area needs such infrastructure urgently. The role of visual media such as television in privatization, attracting domestic investments, and meritocracy which might be because of the abundance of such media in the country and the identity of the strategies, reminds the need for greater coordination and cooperation between the visual media and sports. Another important point is that print media have the most important role in the development of women's sports share which is consistent with the findings of 12 and 3 about the role of mass media in the development of women's sport.

The available evidence presents the role of media, especially the visual media, in supporting women's sports. In other words, the society needs dialogue in terms of demonstrability of the women's sports. But some of the current phenomena such as cultural constraints reflects the fact that scholars must address this problem with more effort in the writing space (print media).

\section{CONCLUSION}

The research findings imply that by identifying the correct and proper use of the media, the most successful results will be gained in attracting foreign investment and hosting an international competition. It is necessary to note that the lack of these two factors is of the major obstacles and difficulties regarding the championship sports development, and their boom is the major way of wealth production in sports of the country. Hence, as the other findings of the study showed that the familiarity extent and implementation of different types of media, new media in particular, is not very optimal in our sports federations (the media are not used desirably by them). Additional effort is recommended to resolve this problem as one of the most important ways of economic evolution in the sports field.

\section{REFERENCES}

1. Ghiamirad, A. A study on marketing strategies for the promotion and development of sports fileds in Iran, Journal of motion, Vol (39): 175-192, 2006.

2. Moradi, J. 2009. Determination strategies of investment strategies in the football industry of the Iran. An unpublished Master's thesis. Islamic Azad University

3. Mahdavian, M., A study on the role of media in women's sports. An unpublished Master thesis. Gilan University. 2008.

4. Elahi, R. and Mozaffari, S.A.A., Athletics national development strategies. Seventh International Conference on Physical Education and Sport Sciences, Institute of Physical Education. Tehran. 2009.

5. Cianfrone, A. and Zhang, J., Different effects of television commercials, athlete endorsements, and venue signage during a televised action sports events. Journal of Sport Management. 20: 322-344. 2006.

6. Dindarfarkosh, F. and Sadrinia, H., Public and media relations. Third edition, Tehran: Publication lighting. 2009.

7. Sajjadi, N., The relationship between using athletic images in advertising and the consumer behavior of the spectators in sports competitions. Journal of motion. 34: 83-93. 2007.

8. Ruddock, A., Contradictions in media sport culture. University of Western. Sydney. Australia. 2010.

9. Ioakimidis, M., Online marketing of professional sports clubs: engaging fans on a new playing field", International Journal of Sports Marketing \& Sponsorship. 282271. 2010.

10. Hur, Y., Ko, Y. J., and Valacich, J., A Structural Model of the Relationships Between Sport Website Quality, ESatisfaction, and E-Loyalty. Journal of Sport Management, 25: 473-458. 2011.

11. Eydi, H. and Ramezani, H., Holding management of Olympic (1948-2008). First International Conference on Privatization and Investment in Sports. Tehran. 2009.

12. Kashgar, S., A survey on the importance of deterrents of Tehranian women participating in recreational sport according to the individual characteristics. Journal of Women's Studies. 14: 89-139. 2007. 